e-ISSN: $1984-4255$ ARGUMENTOS

DOI: https://doi.org/10.36517/Argumentos.24.3

\title{
Natureza e liberdade em Ludwig Feuerbach
}

\author{
Nature and freedom in Ludwig Feuerbach
}

\author{
Eduardo Ferreira Chagas \\ Orcid: https://orcid.org/0000-0003-1957-6117 - E-mail: ef.chagas@uol.com.br
}

\begin{abstract}
RESUMO
O artigo pretende destacar a tese de que a natureza para Feuerbach é um existente autônomo e independente, possui primazia ante o espírito e que ela é a base material da liberdade humana. Para ele, a natureza material, que existe, em sua diferencialidade qualitativa, independente do pensar, é diante ao espírito o original, o fundamento não deduzível, imediato, não criado de toda existência real, que existe e consiste por si mesmo. Feuerbach opõe a natureza ao espírito, pois ele a entende não como um puro outro, que só por meio do espírito foi posto como natureza, mas, como o primeiro, a realidade objetiva, material, que existe fora do entendimento e é dada ao homem por meio de seus sentidos como fundamento e essência de sua vida. Trata-se aqui também de uma exposição da ética materialista, a posteriorística, de Ludwig Feuerbach a partir de sua crítica a toda ética apriorística, transcendental, ilimitada, indiferente, imediata, pura, vazia de conteúdo, abstraída das determinações, da situação concreta, baseada numa liberdade, ou vontade, incondicionada, indeterminada, numa pretensa liberdade humana independente tanto dos limites e das leis da natureza externa, quanto da natureza interna, da determinação corporal e das necessidades naturais humanas. Com isto, não há, todavia, em Feuerbach um determinismo ou uma negação da liberdade, da vontade, mas a defesa de que a liberdade humana não é absoluta e incondicionalmente livre, mas condicionada pelo tempo, pelo momento histórico, pela idade, por meios materiais e sensíveis, pela situação ambiental, pelas condições e circunstâncias da natureza, como alimento, vestimentas, luz, ar, água, espaço e tempo, pois ter vontade é sempre ter vontade de algo, já que ela é sempre vontade mediada por um objeto, e é só, através das condições e mediações, que se alcança a liberdade, e, assim, a liberdade, a vontade, se torna concreta.
\end{abstract}

Palavras-chave: Natureza. Liberdade. Ética. Feuerbach.

\section{ABSTRACT}

The article intends to highlight the thesis that nature for Feuerbach is an autonomous and independent existent, has primacy before the spirit and that it is the material basis of human 
freedom. For him, the material nature, which exists, in its qualitative differentiation, independent of thinking, is the original, the non-deductible, immediate, uncreated foundation of all real existence. Feuerbach opposes nature to spirit, because he understands it not as a pure other, but, as the first, objective, material reality, which exists outside of understanding and is given to man through your senses as the foundation and essence of your life. This is also an exhibition of Ludwig Feuerbach's materialistic, posterioristic ethics based on his critique of all a priori, transcendental, unlimited, indifferent, immediate, pure, contentless ethics, abstracted from determinations, from the concrete situation, based on a freedom, or will, unconditioned, undetermined, on an alleged human freedom independent of both the limits and laws of external nature, as well as internal nature, corporal determination and human natural needs. With this, however, in Feuerbach there is no determinism or denial of freedom, of will, but the defense that human freedom is not absolutely and unconditionally free, but conditioned by time, by the historical moment, by age, by means material and sensitive, due to the environmental situation, the conditions and circumstances of nature, such as food, clothing, light, air, water, space and time, because having a will is always having a will for something, since it is always a will mediated by an object, and it is only through conditions and mediations that freedom is achieved, and, thus, freedom, the will, becomes concrete.

Keywords: Nature. Freedom. Ethics. Feuerbach.

\section{Introdução}

O artigo expõe um aspecto central da Filosofia de Ludwig Feuerbach (1804-1872) que fora, infelizmente, até hoje insuficientemente investigado, a saber, a sua acepção de natureza e a condição desta na determação da liberdade humana, da vontade, da ética. Tem-se aqui, em primeiro plano, a seguinte hipótese: a reflexion de Feuerbach, que se referre, no âmbito de sua argumentation, à autonomia da natureza (Autonomie der Natur) (ou seja, à natureza autônoma, que existe independentemente da consciência humana) e que procura proporcionar-lhe valor, é para se entender como corretivo à religião e à filosofia especulativa, para poder fazer assim, simultaneamente, fronteiras a tais direções que tomaram a liberdade humana como incondicionada, absoluta, a priori e abstrata.. No que tange à pesquisa acerca do entendimento da natureza e da vontade livre, da liberdade humana concebido por Feuerbach, devem ser menciondos, sobretudo, os trabalhos de Werner Schuffenhauer, Peter Cornehl, Ursula Reitemeyer, Alfred Schmidt, I. M. Jessin, Joachim Höppner, Francesco Tomasoni, Heinz Hüsser, assim como as contribuições (em forma de artigos) de Regina Steindl, Gerd Haensch, Gisela Schrötter, Theodor Münz e Hermann Ley. Reitemeyer e Cornehl (mas também Münz e Haensch) que se limitam, em seus escritos, ao conceito de natureza do jovem Feuerbach nos anos 30 (do séc. XIX), sobretudo às obras Dissertação sobre a Razão (Dissertatioüber die Vernunft), Pensamentos sobre a Morte (Todesgedanken), Leibniz, assim como História da Filosofia (Geschichte der Philosophie), nas quais Feuerbach tenta superar, ainda no âmbito de suas concepções panteístas, o dualismo entre espírito e natureza. Enquanto Schmidt e Jessin, do mesmo modo como Höppner, se ocupam, em seus trabalhos, com o significado da concepção de natureza de Feuerbach para Marx, assim como com a crítica de Marx a Feuerbach, e, por isso, recorrem, de preferência, aos seus escritos dos anos de 1839-1842, a saber, Crítica à Filosofia Hegeliana (Kritik der hegelschen Philosophie), Teses Provisórias (Vorläufige Thesen), Necessidade de uma Reforma (Notwendigkeit einer Veränderung) e Princípios (Grundsätze), tratam Francisco Tomasoni, Ley e Hüsser o conceito de natureza de Feuerbach nos seus escritos de maturidade, particularmente 
a partir de 1846 (Cf. SOUZA, 1998, p. 55-93). Já que todos os trabalhos mencionados se limitam, no entanto, somente a uma apresentação isolada, fragmentada, ou seja, se restringem, em primeiro lugar, a um determinado ponto na concepção de natureza, e, às vezes, sua implicação à liberdade humana, em Feuerbach, permanecendo o desenvolvimento e as alterações desta concepção ainda a ser investigados, tem esta pesquisa por objeto, primeiramente, o conceito de natureza de Feuerbach na sua totalidade e, em seguida, sua condição como pressuposto para a vontade libre, para a liberdade humana, apresentando, neste sentido, uma análise mais detalhada e sistemática. Embora a concepção de natureza e sua implicação para a liberdade humna em Feuerbach só se deixe mostrar, de forma mais clara, na sua última fase, ela deve, não obstante, ser tratada como um todo, como resultado da totalidade de sua filosofia. Precisamente por isso, a presente pesquisa tem por tarefa mostrar como Feuerbach desenvolveu os conceitos de natureza e de liberdade (ética) dos anos 30 (do séc. XIX) até os escritos de maturidade e qual funktion e relevância pertencem tais conceitos no interior de sua filosofia.

\section{O conceito de natureza}

Parto do princípio de que a filosofia da natureza de Ludwig Feuerbach tem como cerne uma oposição ao teísmo (seja ao Cristianismo, seja ao paganismo), à filosofia especulativa e ao Idealismo Alemão (Fichte, Schelling e Hegel). O conceito de natureza em Feuerbach constitui uma das questões mais difíceis de sua filosofia e não é, por conseguinte, fácil de ser explorado; ele fora tratado, no âmbito das pesquisas sobre a filosofia feuerbachiana, quase exclusivamente em conexão com sua antropologia e sua crítica filosófica à religião e, em primeiro lugar, reduzido à natureza do homem (Cf. TOMASONI, 1986). Tendo em vista, precisamente, a deficiência das pesquisas até então realizadas, pretendo aqui averiguar o seguinte: que significado atribui Feuerbach, de fato, à natureza em si, se ele próprio se referiu, em seus escritos juvenis, apenas em geral à natureza, se se ocupou primeiro, em sua crítica à religião, tão-somente com o gênero humano e só posteriormente refletiu assistematicamente sobre a natureza? A princípio poder-se-ia, então, perguntar: por que se interessa Feuerbach, como crítico da religião, em geral pela natureza? O que ele entende por natureza e o que ela significa para ele? Existe para ele uma natureza independente, fora do entendimento ou da natureza humana? Como se apresenta para ele a ilação vontade-natureza, ou melhor, como a liberdade humana se relaciona com a natureza? Que lugar destina Feuerbach à liberdade no interior da natureza? Como compreende ele a diferença entre natureza e liberdade? Partindo destas questões, irei aqui desenvolver e explicar, primeiro, o conceito de natureza em Feuerbach. Conquanto ele não tenha empreendido, infelizmente, uma formulação completa de sua concepção de natureza como um todo, isto é, não tenha deixado nenhuma filosofia da natureza explícita e acabada e também não tenha redigido nenhum escrito pormenorizado e sistematizado acerca da natureza, há, todavia, em sua obra, em diferentes passagens, uma abundância de aforismos, epigramas, definitionen e reflexões filosóficas sobre a natureza. Assim, o conceito de natureza de Feuerbach foi desdobrado, em sua obra, na verdade apenas de maneira fragmentada, mas ele está, apesar disto, no centro de sua filosofia. O desenvolvimento e a transformação desse conceito perpassam, de certa maneira, como fio condutor à totalidade da obra de Feuerbach, abrem um caminho para entender a sua filosofia como crítica ao teísmo (Theismus) e ao Idealismo (Idealismus) e nos permitem tratá-la sistematicamente.

A ausência de uma sistematização, ou seja, de uma precisão ou de uma clara posição no que se refere ao conceito de natureza em Feuerbach encontra-se fundamentado nisto: que a pretenção principal de sua filosofia é, como acima aludido, a crítica ao teísmo (sobretudo ao 
Cristianismo) e ao Idealismo (especialmente à filosofia de Hegel), os quais são deficitários em relação à natureza, visto que eles não só abandonaram, mas sobretudo menosprezaram a consideração da natureza. A falta em Feuerbach de uma reflexion decidida, explicitamente formulada sobre a natureza, pode, conseqüentemente, ser entendida, em princípio, como expressão da ausência de uma tematização da natureza no teísmo e no Idealismo em geral. Acerca desta problemática deve ser aqui estabelecido, inicialmente, a tese de que a natureza (Natur) em Feuerbach possui o primado frente ao espírito; ela é a primeira estrutura da existência e frente a ela se põe o entendimento como algo "secundário". Para Feuerbach, a natureza material, que existe, em sua diferencialidade qualitativa, fora e independentemente do pensar, é frente ao espírito o primeiro, o originário. A natureza, entendida como totalidade, como unidade orgânica, como harmonia de causas e efeitos, como pressuposto necessário para todos os objetos, fenômenos e criaturas, plantas e animais, inclusive para a natureza humana, fornece a Feuerbach o fundamento de sua crítica ao teísmo e ao Idealismo, isto é, ela é o motivo de sua konfrontation com ambos, os quais desconhecem completamente a autonomia e a independência da natureza, porque eles a concebem ou meramente como obra de um criador ou como puro desdobramento e exteriorização da atividade do espírito. Em ambos os sistemas foi a natureza tratada, portanto, não como um existente independente, autônomo, mas deduzida apenas como uma grandeza dependente e inconsistente em si mesma. Assim compreendido, mediante um entendimento da natureza que se baseia nas determinações imanentes a ela - imediaticidade, autonomia, regularidade, legalidade universal (lei), exercida impessoal e logicamente, necessidade, dinamicidada - Feuerbach formulará não só sua crítica ao teísmo e ao Idealismo, como também alicerçará, na maturidade, sua teoria da liberdade.

Embora não haja em Feuerbach nenhuma concepção uniforme, homogênea e inequívoca da natureza, é-me permitido constatar o seguinte: a referência à autonomia da natureza (Selbständigkeit der Natur) é o fundamento da crítica, ou melhor, o cerne da reaktion e konfrontation feuerbachiana contra o teísmo e o Idealismo, que se desdobra em três diferentes fases de desenvolvimento: 1. como aproximação crítica ao panteísmo (identidade da natureza com Deus), 2. como recusa direta à teologia cristã e à filosofia hegeliana (a natureza como criação de Deus ou como deduktion do espírito) e 3. como crítica parcial à religião da natureza (antropomorfização ou personificação da natureza). Inicialmente nos escritos de juventude dos anos 20 e 30 (do século XIX), particularmente a Dissertação sobre a Razão (Dissertation über die Vernunft ou De Ratione una, universali und infinita) (1828), os Pensamentos sobre a Morte e a Imortalidade (Gedanken über Tod und Unsterblichkeit) (1830), a Introdução à Lógica e Metafísica (Einleitung in die Logik und Metaphysik) (1829-30), a História da Filosofia Moderna (Geschichte der neueren Philosophie) (1835-36) e a Apresentação, Desenvolvimento e Crítica da Filosofia Leibniziana (Darstellung, Entwiclung und Kritik der Leibnizschen Philosophie) (1837), Feuerbach trata a natureza de um ponto de vista panteísta. Partindo de um panteísmo que se orienta sobretudo em Giordano Bruno, Jakob Böhme e Baruch Spinoza, ele tenta, já nesse período, restabelecer, frente à depreciação da natureza pela religião cristã e em oposição à identidade formal de pensar e ser postulada pela filosofia hegeliana, uma reconciliação entre ser e pensar, uma unidade entre natureza (matéria) e Deus (espírito). No panteísmo Feuerbach vê, na verdade, não só tal reconciliação, mas também a superação do subjetivismo e da personificação de Deus (de um Deus transcendente), e, por isso, o panteísmo sinaliza para ele a solução para os problemas filosóficos fundamentais. Nem Cristianismo, nem Idealismo podem solucionar adequadamente tais problemas, porque eles não têm formulado uma relação adequada para a natureza. Assim como no Idealismo em geral, também no Cristianismo o eu domina o mundo e se considera como o único ser espiritual que existe; nele é redimido apenas a pessoa, não a natureza, o mundo; cen- 
tralizado no eu, na pessoa, o Cristianismo é apenas uma religião, na qual se revela um abandono completo da natureza, pois nele foi consumado uma separação entre a natureza e Deus. Enquanto para o teísmo o espírito é imaterial, não-sensível, transcendente, e Deus uma essência absoluta que existe para si, personificada, extramundana ou estranha ao mundo, admite, ao contrário, o panteísmo, abstraindo aqui as suas diferentes tradições, Deus imerso na natureza; com isto, ele destaca a unidade do mundo com Deus (com o espírito). Se a característica essencial do teísmo é, por conseguinte, o isolamento de uma essência do pensamento, abstraída da natureza pelo homem, existe, ao contrário, no panteísmo Deus no interior da natureza (Cf. CHAGAS, 2007, p. 215-232; CHAGAS, 2006, p. 79-93).

Seguindo a primazia da natureza, que tem seu fundamento em si mesma, e sob a consideração de sua autonomia como objeção (Einwand) ao teísmo e ao Idealismo, percebe-se também o conceito de natureza de Feuerbach em conexão com sua crítica ao Cristianismo e, ao mesmo tempo, em discussão com a filosofia hegeliana, isto é, o segundo período de sua concepção de natureza que envolve, especialmente, os escritos de 1839-43, como Para a Crítica da Filosofia Hegeliana (Zur Kritik der hegelschen Philosophie) (1839), A Essência do Cristianismo (Das Wesen des Christentums) (1841), Teses Provisórias para uma Reforma da Filosofia (Vorläufige Thesen zur Reform der Philosophie) (1842), Necessidade de uma Reforma da Filosofia (Notwendigkeit einer Veränderung der Philosophie) (1842) e Princípios da Filosofia do Futuro (Grundsätze der Philosophie der Zukunft) (1843) (Cf. CHAGAS, 2005). A palavra natureza, não no sentido da natureza humana, isto é, como natureza do homem, do gênero humano, mas, pelo contrário, no sentido da natureza, tal como ela é em si mesma, isto é, no sentido da natureza material, aparece nas obras mencionadas, e isto é visível na obra principal de Feuerbach, A Essência do Cristianismo, muito raramente. Feuerbach não desenvolve aqui nenhuma teoria da natureza, mas a apresenta indiretamente, para defendê-la contra a atitude cristã frente a ela. Ele deixa claro que a teologia cristã se relaciona negativamente perante a natureza (Cf. CHAGAS, 2010, p. 57-82). A depreciação ou desvalorização religiosa pela natureza tem consequências para o julgamento da natureza humana por parte da teologia, pois esta condena também a dimension natural-sensível da natureza do homem e, frente a esta, enaltece o espírito. Este entendimento negativo do cristão para coma natureza, torna-se, por exemplo, mui evidentenão só na Doutrina da Criação (Kreationslehre), mas também na Doutrina do Pecado Original (Erbsündeslehre), pois esta, fundada no desdém pela natureza, baseia-se num sentimento de culpa condicionado pela falha e fraqueza do homem e, por isso, na negação de sua corporeidade, de sua sensibilidade presa à natureza. Uma confirmação para isso acha-se também nisso, a saber, que o homem deve, de acordo com o entendimento cristão, livrar-se precisamente de sua natureza corporal (da "natureza transgredida") para merecer e conseguir a vida eterna, sem as "tentações" e os desejos da carne. Precisamente porque a natureza expressa objetividade, necessidade, corporeidade, sensibilidade, é ela o negativo, por assim dizer uma prova dos limites da liberdade humana, da interioridade, do sentimento religioso, isto é, a barreira concreta que se opõe à illusion de uma existência sobrenatural. Deste ponto de vista cristão, ela deve, portanto, ser eliminada, negada. Feuerbach argumenta que Deus (o todo supremo, a essência sublime), o qual a imaginação religiosa criou, é apenas uma representation fantasmagórica do gênero humano, uma konstruktion subjetiva do homem, abstraída de todas as fronteiras e restrições da natureza, e a religião serve ao homem de meio, com o qual ele tenta livrar-se da natureza.

Partindo desse entendimento acerca da natureza, pode-se constatar uma última fase da concepção de natureza em Ludwig Feuerbach, não só aos escritos fundamentais de 1846-48, como A Essência da Religião (Das Wesen der Religion) (1846), Complementos e Esclarecimentos para a Essência da Religião (Ergänzungen und Erläuterungen zum Wesen der Religion) (1846), 
Preleções sobre a Essência da Religião (Vorlesungen über das Wesen der Religion) (1848), nos quais Feuerbach, apoiando-se na religião da natureza, critica a natureza como objeto da religião e a toma como base e fundamento do homem e de todas as coisas, bem como aos seus escritos maduros, como A Pergunta pela Imortalidade sob o ponto de vista da Antropologia (Die Unsterblichkeitsfrage vom Standpunkt der Anthropologie) (1847), A Ciência da Natureza e a Revolução (Die Naturwissenschaft und die Revolution) (1850), O Segredo do Sacrifício ou O Homem é aquilo que come (Das Geheimnis des Opfers oder der Mensch ist, was ißt) (1860), Sobre Espiritualismo e Materialismo (Über Spiritualismus und Materialismus) (1866) e Para uma Filosofia Moral (Zur Moralphilosophie) (1868), nos quais ele tenta fundir uma relação fundamental entre filosofia e ciência da natureza. Se, em A Essência do Cristianismo (Das Wesen des Christentums), o fundamento e também o objeto da religião eram ainda a essência moral do homem, abstraída da natureza, quer Feuerbach agora, nesses escritos maduros, superar todo discurso (oratio) antropológico, teleológico ou teológico em relação à natureza, ou seja, obter a separação da mesma da reductio ad hominem, de todos os predicados humanos. Assim, ele fez a si, por tarefa, defender, justificar e fundamentar a autonomia da natureza contra os esclarecimentos e as deduções teológicas frente a ela. Enquanto ele avaliava a relação cristã em relação à natureza, no todo, negativamente, porque a natureza no Cristianismo está submetida arbitrariamente ao afeto religioso, julga ele, agora, a religião da natureza (Naturreligion) parcialmente positiva, já que ela tem por objeto a natureza (o deus físico) e, por isso, ela exerce uma função importante no que diz respeito a uma percepção adequada da natureza. Não obstante, não se trata para Feuerbach, de maneira nenhuma, de defender a religião da natureza em si, embora ela faça valer, de fato, a natureza, na medida em que ela põe no lugar da liberdade abstrata, da adoração à humanidade, a natureza. Portanto, ele não está interessado na religião da natureza enquanto tal, mas, meramente, em sua função estratégica para a sua argumentation contra o Cristianismo e o Idealismo, pois ela manifesta a natureza, aponta uma indicação decisiva para a verdade dos sentidos, demonstra o significado da sensibilidade e atesta o sentimento de finitude do homem e de sua dependência não de algo sobrenatural, mas da natureza mesma.

\section{A determinação natural da liberdade, da vontade livre}

Na segunda parte deste artigo, destinada à implicação da natureza na determinação da liberdade humana, mostro que Feuerbach, particularmente, em sua obra Sobre Espiritualismo e Materialismo (Über Spiritualismus und Materialismus) (1866), nega a admissão e a ideia de uma liberdade, de uma vontade, de um querer, de um livre-arbítrio (Willensfreiheit) sobrenatural, ilimitado, independente, autônomo. Nesta obra, Feuerbach afirma inicialmente que, na disputa entre materialismo e idealismo, não se trata, para ele, em última instância, da questão da divisibilidade ou indivisibilidade da matéria, não de sua eternidade ou temporalidade, não da existência de Deus, mas, pelo contrário, da divisibilidade ou indivisibilidade do homem, de seu ser ou não-ser, de sua temporalidade ou eternidade. O materialismo "é para mim", assim assegura Feuerbach explicitamente, a base sólida da moral, «o fundamento do edifício da essência e do saber humanos; mas ele não é para mim, como ele é no sentido estrito para os fisiólogos, os cientistas da natureza, por exemplo, para Moleschott, e é, na verdade, a partir de seu ponto de vista e profissão, o próprio edifício.» (FEUERBACH, 1874, p. 308). Em relação à ciência da natureza, frente ao materialismo vulgar par excellence, que foi representado, por exemplo, por Karl Vogt, Karl Moleschott e Karl Ludwig Büchner e permaneceu ligado, principalmente, a uma absolutização das disciplinas biológicas e à ideia darwiniana de desenvolvimento, Feuerbach acentua suas diferenças da seguinte maneira: «A anatomia, a fisiologia, a medicina, a química 
não sabem nada sobre a alma, sobre Deus etc [...]. O homem é a mim, como a eles, uma essência natural, nascida da natureza, mas o meu objeto principal são as ideias e as essências da fantasia, que na opinião e na tradição dos homens valem como essências reais.» (FEUERBACH, 1874, p. 188). Na verdade, Feuerbach concorda com o materialismo nisto, a saber, que ambos reconhecem a matéria como o elemento primitivo, como a matéria-prima (Urstoff) de toda a realidade e o conhecimento sensível como o primário do conhecimento racional, mas o seu materialismo não é, como ele diz, uma «monstruosidade», uma "deformidade da modernidade", mas, pelo contrário, a confissão consciente da fonte da existência humana, ou seja, da natureza, da qual resulta para ele, em última instância, a condição fundamental para qualquer forma de desenvolvimento humano. Por isso, Feuerbach critica aqui os filósofos especulativos, os espiritualistas e teólogos, que atribuem ao homem uma liberdade (Freiheit), uma vontade (Willen) independente, livre das determinações e condições de sua essência real, de todas as leis da natureza e, precisamente por isto, de todas as tendências naturais, as inclinações, as pulsões, os instintos (Trieben) sensíveis.

Para provar a tese da liberdade absoluta (der absoluten Freiheit), ou seja, que o homem age segundo uma liberdade incondicionada, uma vontade livre (einem freien Willen), os filósofos especulativos, os espiritualistas e teólogos remetem ao suicídio (Selbstmord), que representa para eles o poder da substância espiritual sobre a vida. Se se aceita tal prova, assim se permite entender, de acordo com eles, a liberdade de forma a priori, puramente subjetiva, indeterminada, isto é, a liberdade, o querer, a vontade, não ligados às leis da natureza, aos vínculos que encadeiam a vida. Grande número de argumentos desse tipo encontra-se, por exemplo, em Sêneca, que elege a seguinte formulação: "'Por toda parte está ao homem o caminho livre para a liberdade. [...] A liberdade depende dele."' (SENECA, 1999, Bd. 1, p. 259)1'. Também Jacobi diz: "Para escolher entre a morte e a vida não pode nenhum animal: ele tem apenas instintos sensíveis, que se dirigem todos para a conservação, manutenção, instintos que o forçam apenas a continuar a sua existência na terra. - Isto o homem pode"' (FEUERBACH, 1874, p. 54). Em Sófocles, diz Antígona à sua irmã Ismênia: "'Tu escolheste, sim, a vida, e eu, a morte."' (SÓFOCLES, 2000, p. 27) ${ }^{2}$ Fichte escreve em seu Sistema da Doutrina Moral (System der Sittenlehre):"A decisão para morrer é a representação pura da supremacia do conceito sobre a natureza. Na natureza encontra apenas o instinto para se manter, e a decisão de morrer é exatamente o oposto deste instinto. Qualquer suicídio exercido com fria prudência [...] é um exercício daquela soberania."' (FICHTE, 1997, § 20, Cap. 534)3. Semelhantemente, Hegel argumenta nos Princípios da Filosofia do Direito: "'No elemento (na pura indeterminidade) da vontade reside que eu posso me desprender de tudo [... .], me abstrair de tudo. Só o homem pode desistir de tudo, até mesmo de sua vida, ele pode cometer um suicídio."' (HEGEL, 1999, p. 63)4. Para Feuerbach, é, no entanto, questionável, duvidoso, se instinto de autoconservação (Selbsterhaltungstrieb) e suicídio (Selbstmord), ou natureza (Natur) e liberdade (Freiheit), estão realmente em um tal contraste de um para com o outro. Para ele, necessidade (Notwendigkeit) e liberdade (Freiheit) estão mesmo ligados um com o outro, pois não há, segundo sua opinião, na natureza um instinto puro de autoconservação, até mesmo o instinto de autoconservação de um animal também está em conexão com a «liberdade» de seu movimento e com outros animais de sua espécie. Uma ação é, pois, livre, quando ela acontece também com necessidade de suas próprias potências, de suas possibilidades. «Livre é o pássaro no ar, os peixes na água, livre está qualquer ser lá onde ele se encontra

\footnotetext{
1 Cf. ainda (SENECA, 1999, Bd. 3, p. 83 e 407); (FEUERBACH, 1972, p. 60-61).

2 Também conferir (FEUERBACH, 1874, p. 54).

3 Também conferir (FEUERBACH, 1874, p. 54).

4 Também conferir (FEUERBACH, 1874, p. 54).
} 
e age em concordância com sua essência» (FEUERBACH, 1874, p. 83). "Dizemos», ele acentua, dando sequência ainda mais claramente, «que a macieira produz maçãs pela necessidade, apenas por isto, e não pela liberdade da vontade, pelo livre-arbítrio, porque ela só produz maçãs, e, na verdade, apenas maçãs sempre da mesma espécie e qualidade; apenas por isso, nós negamos ao pássaro a liberdade de cantar, porque ele canta sempre as mesmas canções, por isso não pode cantar outras." (FEUERBACH, 1967, 271). Mas o instinto de auto-conservação no animal está ligado intimamente ao «instinto de liberdade», pois quando um animal, que não suporta de modo nenhum o cativeiro, perde a sua a liberdade, perde ele, simultaneamente, 0 apetite e morre num curto espaço de tempo.

Comparado com os demais seres orgânicos da natureza, como animais, árvores, plantas etc., Feuerbach não entende o homem, como os materialistas franceses, como uma natureza puramente física, ou seja, determinado de tal forma unilateral, pois ele não é apenas escravo, mas também senhor da natureza. Assim, por exemplo, ele não produz, como as árvores, "sempre as mesmas frutas»; "ele não canta sempre as mesmas canções, como o pássaro, ele canta ora esta, ora aquela, ora uma triste, ora uma alegre. Diversidade, pluralidade, variabilidade, irregularidade, ilegalidade são apenas os fenômenos, os efeitos, cujas causas nós pensamos a nós como um ser livre, de vontade." (FEUERBACH, 1874, p. 271). Entretanto, não há no homem uma liberdade plena, sem limites (schrankenlose Freiheit), pois esta não está em contradição, mas em consonância com seu instinto de autoconservação, com as suas inclinações e seus instintos. A liberdade estende no instinto de autoconservação o seu próprio ser, a sua vida, vida essa que tal instinto não pode separar de si, sem renunciar a si mesmo. Por conseguinte, Feuerbach não aceite o suicídio como suposta prova para a liberdade da vontade, do livre-arbítrio humano, para uma liberdade incondicional (unbedingte), ilimitada (uneingeschränkte), pois ele não é uma autodestruição sem fundamento, isolada das condições concretas, que pertencem necessariamente à vida dos homens; assim um homem renuncia a todas as satisfações da vida apenas para renunciar a uma existência inautêntica, marcada pelo sofrimento, pelo desespero, pela dor, pelas aflições, ou seja, para subtrair de si as sobrecargas, as violações e as infelicidades da vida. O suicídio é, portanto, tratado em si e para si mesmo apenas como um protesto contra uma vida degradante, antinatural, antihumana, contra os males da sociedade, como um «veneno» contra um veneno, pois ele nega a natureza não em sua condição plena, saudável e feliz, mas em sua condição mutilada, sofrida e infeliz. Por conseguinte, o pressuposto ou a causa primeira da desistência espontânea, da renúncia voluntária à vida não é a liberdade (die Freiheit), o querer, a vontade (der Wille), mas, pelo contrário, a necessidade (die Notwendigkeit), a privação (die Entbehrung), pois, antes que o suicida se mate, estavam já a ele desaparecidas as possibilidades da vida, os meios necessários para viver. Portanto, um homem não se mata pelo simples fato de querer morrer, pois a vontade para o suicídio não é, de modo nenhum, livre, mas determinada pelas circunstâncias concretas da vida. A frase "eu quero morrer» ("Ich will sterben") é, segundo Feuerbach, então "apenas a conclusão consentida da contrariada frase principal: eu não posso mais viver, eu devo morrer.» ("Ich kann nicht mehrleben, ich mußsterben") (FEUERBACH, 1874, p. 56). Isto significa: alguém renuncia a sua vida, quando ele, sem aquilo o que é necessário e indispensável à sua própria vida, não pode viver. Com isto o suicídio, a separação, que está ligada com o fim, confirma e expressa apenas a inseparabilidade das condições da natureza, a necessidade da vida mesmo. Pois a vontade, que aniquila o corpo, aniquila, então, também a si mesmo e, com isto, comprova, de fato, que ela não é nada sem um corpo, sem as possibilidades da vida, sem os meios de subsistência. Em oposição a Hegel, que em sua Filosofia do Direito (Rechtsphilosophie), argumenta que "'eu"' tenho "'esses membros, a vida apenas"', '"na medida em que eu quero; o animal não pode mutilar-se ou suicidar-se, mas o homem "' (HEGEL, 
$1999, \S 47$, p. 59) ${ }^{5}$, é certo para Feuerbach que eu não tenho «meu corpo por causa da minha vontade, mas, pelo contrário, só tenho vontade por causa de meu corpo e de minha vida.» (FEUERBACH, 1874, p. 58). A liberdade de se abstrair de tudo, ou a liberdade da vontade, o livre-arbítrio erguido sobre todas as necessidades da natureza do livre-arbítrio só seria, então, possível, se o homem também pudesse abstrair da vida e da morte, isto é, se vida e morte dependessem apenas de sua vontade. Pois, se o homem fosse, realmente, absolutamente livre, assim o suicídio seria, completamente, sem sentido, inútil. Mas, já que a vida e a morte não estão no poder de sua vontade, isto prova que não há liberdade, vontade, cujo fundamento último não se encontre na natureza, ou seja, que não tenha ainda nela as suas raízes.

Partindo de seu ponto de vista materialista, Feuerbach defende, assim, a determinação natural da liberdade, da vontade humana. Já nas Preleções sobre a Essência da Religião (Vorlesungen über das Wesen der Religion) tinha ele esclarecido:

Eu sou o que sou, [...] enquanto apenas uma parte da natureza como ela é constituída neste século, pois também a natureza se transforma, por isso todo século tem a sua própria doença, e eu não me pus neste século por minha vontade. Mas, eu não posso, não obstante, separar tão-pouco minha essência da essência deste século, assim como não posso pensar a mim como uma essência que existe fora da mesma, uma essência independente dela, tão-pouco minha vontade separada desta essência; eu estou comprometido com esta sorte ou destino, com esta necessidade de ser membro desta época, eu posso querer ou não, eu posso estar ou não consciente disto; eu sou o que sou por natureza, o que eu sou sem vontade e, igualmente, com vontade; eu não posso querer ser nada mais além do que eu sou, isto é, sou em essencialmente ou segundo a essência. Minhas qualidades indiferentes, acidentais, eu posso pensar de outra forma, posso querer mudá-las, mas não minha essência; minha vontade é dependente de minha natureza, de minha essência, mas minha natureza não depende de minha vontade; minha vontade se guia pela minha essência, também sem que eu saiba e queira isto, mas minha essência, isto é, a qualidade essencial de minha individualidade, não se guia pela minha vontade, por mais que eu ainda também me esforce e me ofereça tanto para isto. (FEUERBACH, 1874, p. 184-185).

Apenas porque o homem pode e deve morrer, pode ele, então, também querer morrer. A liberdade de querer morrer, a vontade de morrer tem, por conseguinte, já a morte inevitável para seu fundamento e apoio. Isto torna-se já claro em Sófocles, quando a condenada Antígona à morte diz ao Creonte: "Que devo morrer, isto eu já sabia também sem a tua proclamação." (SÓFOCLES, 2000, p. 22) ${ }^{6}$ Ideias semelhantes manifesta também a llíada (Ilias) de Homero, quando Sarpédon diz contra Glauco: "Seguramente, seria a nós permitido, fugir desse combate, para permanecer sempre imortal na juventude nunca envelhecida. Nem eu mesmo, pois, lutava, misturado nas lutas de frente, nem também eu te convido para a batalha que satisfaz os homens. Mas isto porque surge, sim, a nós inúmeras vezes o destino da morte, ao qual nenhum mortal escapa, nem o evita, porque nós glorificamos outra glória ou a nossa!"' (HOMERO, 1979 , p. $448 ; 492)^{7}$

Com passagens literárias, como estas, Feuerbach quer provar que a morte (der Tod) não está em contradição com a necessidade da natureza (Naturnotwendigkeit), da vida (Leben). Na verdade, o desejo, a vontade (der Wunsch), a liberdade, a determination para morrer seria, no sentido idealista, uma decisão supranatural, sobrenatural, se houvesse apenas uma morte voluntária, espontânea, mas não necessária, natural, ou seja, se o homem sacrificasse não sua vida mortal, mas imortal. A morte pode ser, então, concebida como um objeto da liberdade, da vontade? Vida e morte (Leben und Tod) dependem apenas da nossa vontade, da liberdade (Freiheit)?

\footnotetext{
5 Cf. também (FEUERBACH, 1874, p. 57-58).

6 Cf. também (FEUERBACH, 1874, p. 58).

7 Cf. também FEUERBACH, 1874, p. 58).
} 
Só vivemos porque queremos viver e, por conseguinte, podemos querer, a todo momento, 0 contrário, a morte? A tais perguntas responde Feuerbach: com certeza, o homem pode matar a si mesmo, se ele quer se matar. Mas esta decisão não está fundamentada apenas subjetivamente, moralmente, mas também naturalmente, fisicamente, pois ela não depende simplesmente do desejo, da pura vontade, da liberdade. O homem quer a morte apenas porque esta é para ele uma necessidade (eine Notwendigkeit), pois onde não há nada contra a vida, lá não há também fundamento para a morte. Por conseguinte, é sem fundamento, ou seja, uma mera imaginação do homem a acreditar que sua vida (e até mesmo o suicídio) dependa apenas da liberdade, da graça de sua vontade. Em Feuerbach vale, em vez da frase: «Eu posso o que eu quero» ("Ich kann, was ich will"), o princípio: «Eu quero o que eu posso» ("Ich will, was ich kann"). O fundamento da liberdade, da vontade, para ele não é, então, o querer imaginário, sem base, que quer algo que ela não possa, mas o poder, a potência, a possibilidade do querido. Precede à liberdade, à vontade, portanto, apenas aquilo que é da natureza. Isto se manisfesta para Feuerbach, por exemplo, na frase:

Eu quero ser músicos, [na verdade, uma vontade], mas esta vontade é [...] apenas é a revelação de meu talento para a música. Tão pouco eu posso gerar crianças pela pura liberdade, pela pura vontade sem a potência de procriação, tão pouco pode em geral [a liberdade], a vontade algo sem utensílios, sem matéria, sem órgão para aquilo que ela quer. Para onde falta o sentido, a disposição, para isto falta também [a liberdade], a vontade. Onde querer e poder estão em contradição, como tão frequentemente na vida burguesa, lá aparecem, precisamente por isto, criaturas disformes. (FEUERBACH, 1874, p. 59-60).

Quanto à morte, o homem pode apenas desejá-la lá onde ele em si tem fundamento para ela. A morte é necessária, pois sem ela seria ilimitada, sem medida, a vida do homem e todo instinto de auto-preservação. Na verdade, não há um abismo entre vida (Leben) e morte (Tod); a morte natural resulta de acordo com as leis da natureza e pertence à vida, pois toda vida é, seja por doença, seja por idade, levada à morte. Contrário ao cristão, que parte de um pressuposto antinatural, ou seja, pressupõe que a morte é um puro mal, uma consequência da punição, do castigo de Deus pelos pecados cometidos, Feuerbach a entende como um bem; a morte "é a recompensa pelas lutas aos sofrimentos passados.» (FEUERBACH, 1874, p. 61) . $^{\text {. O }}$ homem deve, portanto, ver na morte não apenas o fim de sua vida, mas também a morte da morte, o não-ser do não-ser, ou seja, a liberdade de todo o mal, daquilo que dificulta e elimina as condições de sua vida.

Sem dúvida, a posição e o movimento dos corpos dependem da liberdade, da vontade do homem, mas apenas porque esta liberdade, esta vontade, é uma expressão, fundada organicamente, de sua conexão interna com o cérebro, com os nervos e músculos. Pois uma liberdade, uma vontade, arrancada da natureza, da conexão do sistema nervoso e muscular, que os filósofos da moral supranatural, sobrenatural proclamam, é para Feuerbach não uma vontade real, mas apenas um desejo fantástico, imaginação, ou seja, «absurdidade» ou «irracionalidade». Esta liberdade, esta vontade (Wille) desnaturada (unnatürliche), arbitrária (willkürliche), onipotente (allmächtige), que não se baseia na natureza e nas condições do espaço e tempo, pode tudo o que ela quer. Ela se expressa, dito curtamente, assim: «Eu quero, logo eu tenho», ("Ich will, also habe ich"); volo, ergo cogito (eu quero, logo eu penso) (ich will, also denke ich). Fichte

\footnotetext{
8 Também, na obra Preleções sobre A Essência da Religião, Feuerbach expressa sua visão positiva sobre a morte: "Se realizasse essa vontade [a vontade da vida eterna], os homens receberiam satisfeitos, de coração, a vida eterna e teriam saudades da morte. Na verdade, o homem não deseja a si apenas uma morte pré-matura, violento, terrível. [...] A morte normal, natural, a morte do homem consumado, que gozou bem a vida, portanto, não tem, por conseguinte, absolutamente nada de assustador. [...] Somente o falecimento não-natural, infeliz, a morte de criança, de jovem, de homem em sua plena maturidade, indigna-nos contra a morte e cria a vontade de uma nova vida." (FEUERBACH, 1874, p. 311).
} 
corrige já no Sistema da Doutrina Moral (Das System der Sittenlehre) a frase «eu posso o que eu quero» ("Ich kann, was ich will"), quando ele acrescenta: "Nós podemos na verdade tudo o que nós apenas podemos querer.'» (FICHTE, 1997, Bd. 4, § 7, Cap. 519) ${ }^{9}$. Aqui foi feito inteiramente correto, segundo o ponto de vista de Feuerbach, a liberdade, a vontade, dependente das possibilidades, o querer dependente do poder, pois, se depende só do querer, não do poder, eu posso, por exemplo, como Feuerbach observa ironicamente, «querer voar, e posso voar, e, na verdade, sem asas ou órgãos artificiais de vôo, assim eu posso querer me transferir num momento da Europa para América ou da terra para a lua.» (FEUERBACH, 1874, p. 158). Nestes exemplos mostra-se a «irracionalidade» de uma liberdade, de uma vontade, que não tem base material e deve ainda, a partir do nada, produzir efeitos materiais, ou seja, de uma liberdade, de uma vontade, que não depende e não está condicionada pela lei da natureza, pelo organismo corporal, físico, do homem. Na vinculação pela natureza, o homem tem consciência dos limites de sua liberdade, pois como ele "seria feliz», assim pensa Feuerbach, "se sua vontade não fosse uma força imanente ao seu organismo, mas uma força transcendente, isto é, sobrenatural [...], uma força não ligada à matéria, consequentemente também não ligada à matéria médica! Então ele precisaria, sim, apenas querer para ser saudável - e ele seria saudável.» (FEUERBACH, 1874 , p. 170). Feuerbach concebe, assim, a liberdade, a vontade, num sentido limitado pelo poder, pois, para ele, o homem pode o que ele quer, mas apenas na medida em que ele quer, o que ele pode; ou seja, ele só pode querer ou querer realizar o que ele pode realizar de acordo com os limites do seu organismo físico, com o fundamento da natureza, da física e das forças orgânicas. Esta limitação não resulta de um eu, mas daquele não-eu fichteano, da natureza, e é, por isso, uma determinação contrária e adversa, que contradiz o desejo de uma vontade absolutamente livre, sem espaço e sem tempo. Quando se apreende, todavia, o homem não como um membro da natureza e na vontade rompe sua ligação com ela, aparece, pois, uma série de saltos da liberdade que ultrapassa os limites, as fronteiras, as determinações e condições objetivas da natureza.

A liberdade, a vontade livre, existe, portanto, não in abstracto, sem diferença, livre da necessidade, pois ela não é um poder fantástico, sobrenatural, miraculoso poder, ou seja, não uma potência pronta, disposta para todo tempo e em todo lugar para toda realização qualquer, à vontade. Como Feuerbach acentua, a vontade livre é, na verdade, «autodeterminação, mas no interior de uma determinação da natureza independente da vontade da natureza do homem.» (FEUERBACH, 1874, p. 68). Apenas o determinado, ou seja, aquilo que veio aqui e agora para os sentidos e, por meio destes, à consciência, é objeto da vontade. «'A vontade do homem é seu reino celestial', mas o reino celestial do adolescente não é o do jovem e o reino celestial do jovem não é o reino celestial do homem ou do ancião.» (FEUERBACH, 1874, p. 62). Já que a vontade é determinada e, portanto, ligada ao espaço e tempo, o homem não deve querer realizar o que ele não pode fazer no âmbito desse limite. Mas o que ele «não pode aqui e agora», acrescenta Feuerbach, ele «pode isto» talvez «em outro lugar e em outro tempo.» Pois só «quando chega o tempo para algo, chegam também a força e a vontade para isto.» (FEUERBACH, 1874, p. 62). A limitação da vontade através da natureza, através do tempo e do espaço, é para Feuerbach a prova de que a liberdade não é a priori, mas a posteriori, ou seja, que ela se realiza na história. Feuerbach aceita, portanto, uma negação determinada do tempo para a vontade, para a liberdade. Esta negação não se estende, no entanto, ao tempo em geral, mas apenas a uma forma particular do mesmo, pois essa negação não está localizada no além, mas se realiza, pelo contrário, no aquém, isto é, sempre no interior do próprio tempo. Assim, pode-se, por exemplo,

9 Também conferir (FEUERBACH, 1874, p. 159). 
abstrair-se deste ou daquele tempo, do tempo para desfrutar, comer e beber, para brincar, para passear, ou para trabalhar, mas não do tempo pura e simplesmente, por excelência. Da mesma forma, não se deve negar em geral a carência, a necessidade, apenas para poder colocar por meio desta negação a liberdade. Kant faz, abstraindo da forma de existência do tempo, independente das condições empíricas, da forma simples da lei objeto e fundamento de determinação da vontade e concebe, desta maneira, a vontade como uma potência especificamente diferente e independente da potência sensível do desejo, e, precisamente por isto, como vontade pura, como uma "coisa do pensamento». «O homem deve», escreve Braun, "possuir uma potência ativa, que é determinada pela lei, independente de todas as aspirações sensíveis. Esta potência é em Kant a vontade pura.» (BRAUN, 1971, p. 111). Em oposição a isto, Feuerbach diz que a liberdade, a vontade livre, é "uma palavra que só tem sentido, se ela estiver relacionada com uma outra palavra principal ou antes [...] com a palavra tempo». (FEUERBACH, 1874, p. 72). Com isto, ele refuta os argumentos dos moralistas sobrenaturais que acreditam que a liberdade, a vontade livre, está fora ou além do tempo, que ela é autônoma, independente e livre da natureza. Para ele, a vontade é, pelo contrário, apenas vontade no interior da necessidade da natureza, pois ela sob as condições da finitude está completamente ligada ao tempo, ao espaço e à causalidade, à realidade objetiva, à natureza.

Com o "eu quero» ("Ich will") está, de acordo com Feuerbach, ligado inseparavelmente a interrogação "o que» ("Was"), pois uma liberdade, uma vontade livre, separada da matéria, das condições da liberdade, da vontade, significa renúncia, abandono ou supressão da própria liberdade, da vontade. A liberdade, a vontade livre, não pode, assim, ser vista como uma potência separada da naturalidade do homem (Natürlichkeit des Menschen), por isso representa, em Feuerbach, a «ligação da vontade com o instinto de auto-preservação a tentativa de descrever o homem como um ser dominado pela natureza e ainda assim independente.» (HÜSSER, 1993, p. 122). A vontade humana é no fundo desejo (désir), (Verlangen), apetite (appetitio), (Begierde), cujo objeto é o prazer (Vergnügen); a ela serve de base a dependência do homem da natureza, o instinto, o instinto de auto-preservação, que está de acordo com a aspiração pela felicidade (Glückseligkeit). «Onde [...] não há um instinto", uma inclinação, um apetite, "não há vontade, mas onde não há instinto de felicidade, não há instinto em geral. O instinto de felicidade é o instinto dos instintos.» (FEUERBACH, 1874, p. 70). O que o homem aspira, então, é nada mais do que o bem-estar (bienêtre), o fim de uma carga, de um mal, de um sofrimento, de uma dor, ou seja, de todas as contrariedades de sua vida. «A vontade moral é a vontade moral que não quer fazer nenhum mal, porque ela não quer sofrer nenhum mal. Sim, somente a vontade, que não quer sofrer nenhum mal, portanto, só o instinto de felicidade, é a lei moral e a consciência, que detém ou deve deter o homem de fazer o mal.» (FEUERBACH, 1874, p. 80). O postulado de Feuerbach «eu quero» ("Ich will") significa, portanto, em poucas palavras, «eu quero ser feliz» (Ich will glücklich sein); o sentido da vontade é que ela quer realmente a felicidade. Se o primeiro dever do homem é fazer a si mesmo feliz (glücklich), é preciso, então, perguntar aqui, como ele vem, agora, do instinto individual de felicidade, de seu amor-próprio, de seu egoísmo, para o reconhecimento do instinto de felicidade de outro homem? Como a felicidade do eu está em conformidade com a felicidade do tu, a auto-afirmação com a abnegação de si mesmo? A partir da experiência de seu próprio instinto de felicidade, o homem sabe o que é bom (Gut) ou mau (Böse), o que é vida (Leben) ou morte (Tod), amor (Liebe) ou ódio (Hass). Esta conformidade, este acordo, reside, portanto, nisto «que eu, na medida em que torno a mim mesmo feliz, ao mesmo tempo torno o outro eu feliz; que eu quero satisfazer o meu instinto de felicidade apenas de acordo com o teu instinto de felicidade.»(FEUERBACH, 1874, p. 77). Segundo Feuerbach, é, na verdade, direito do homem querer sua própria felicidade, mas é igualmente 
seu dever também reconhecer e afirmar a felicidade do outro, porque o seu instinto de felicidade é satisfeito na e por meio da satisfação do instinto de felicidade do outro. Pois o que «não se deseja que a nós seja feito, não se deve também fazer ao outro!» Ou: «Tudo o vós quereis, que as pessoas devam fazer a vós, isto fazeis vós a elas.» (FEUERBACH, 1874, Bd. II, p. 330). Feuerbach trata aqui a natureza (die Natur) como base da moral (Basis der Moral), porque ela é, precisamente, o fundamento da vida (Grundlage des Lebens) e produz não apenas um instinto de felicidade unilateral e exclusivo, mas também duplo e recíproco; por isso, ela não pode também satisfazer o instinto de felicidade de um singular, sem ao mesmo tempo satisfazer o instinto de felicidade de todos os outros indivíduos. Para Feuerbach, a moralidade não deve ser esclarecida e deduzida de uma razão pura, de um eu puro pensante, sem os sentidos, pelo contrário é para esclarecê-la a partir da ligação do eu com tu. «Onde fora do eu não há um tu, um outro homem, também não se pode falar de moral, apenas o homem social é o homem. Eu sou eu apenas por ti e contigo. Eu sou apenas consciente de mim mesmo apenas porque tu estás defronte de minha consciência como um eu visível e palpável, como um outro homem." (FEUERBACH, 1874, p. 287). Assim, Feuerbach não fundamenta a sua ética sobre um conceito abstrato de dever, como Kant, mas sobre a vida, sobre a felicidade do homem em geral; a felicidade, "que divide para diferentes pessoas, que compreende eu e tu», é para ele «o princípio da moral» (FEUERBACH, 1874 , p. 75). Uma moral, que não está constituída da natureza, da vida, que separa o dever do instinto de felicidade e faz do eu pensado só para si mesmo o seu ponto de partida, interpreta Feuerbach como uma norma humana arbitrária, uma pura fiktion ou uma mera casuística. Um abstrair da moral do princípio da felicidade (Glückseligkeitprinzip) não é para Feuerbach possível. Sem o reconhecimento da felicidade do outro fica suprimido o fundamento e o objeto do dever pelos outros, até mesmo a base da moralidade, pois onde não há uma diferença «entre a felicidade e a infelicidade, entre o bem e o mal», aí «não há também diferença entre o bom e o mau». «Bom é a afirmação, mau a negação do instinto de felicidade.» (FEUERBACH, 1874, p. 75$76)^{10}$.É, por conseguinte, tarefa da moral fazer da determinação do eu instinto de felicidade do tu, o vínculo entre uma e outra felicidade, fundamentada na necessidade da natureza, a lei do pensamento e da ação humana.

Para Feuerbach, o materialismo (Materialismus) (ou o sensualismo) (Sensualismus) é a base, o fundamento sólido dos princípios da moral, porque apenas ele, partindo da sensibilidade (Sinnlichkeit), traz o homem real, individual à existência e o liga por meio dela com o outro. Assim, a filosofia, separada da sensibilidade ou que nega a verdade dos sentidos, não só não sabe nada de particularidade e individualidade, como também se aniquila completamente. Em Feuerbach, a verdadade da vida, da individualidade, funda-se, pelo contrário, apenas na verdade dos sentidos, pois precisamente lá, onde os sentidos, que são a certeza da realidade imediata, elevam-se ao pensamento, começa a individualidade, a diferença. Feuerbach afirma que o homem sabe apenas através dos sentidos, que ainda existem outros seres, outros homens, fora dele, que ele é, então, um ser individual, diferente deles. «Eu sou», diz Feuerbach, «não o homem em geral numa determinada forma, eu sou apenas homem como este homem determinado; homem-ser e este individuum-ser é de modo nenhum separável em mim.» (FEUERBACH, 1874, p. 103-104). Mas esta individualidade do homem não se afirma "de modo nenhum, apenas, como na representação comum dela, na diversidade do sentimento e do juízo sobre o mesmo objeto, mas também

\footnotetext{
${ }^{10}$ Nas Preleções sobre A Essência da Religião, (Vorlesungen über das Wesen der Religion), Feuerbach tinha sublinhado: o bem não é uma ideia ontológica, um predicado de Deus, encontra-se, pelo contrário, "mesmo na natureza humana, [...] no egoísmo humano o bem nada mais é do que o que corresponde ao egoísmo de todo homem, o mal nada mais do que o egoísmo de um classe singular de homens, a custa de outros [...], mas o egoísmo de todos, ou também pelo menos da maioria, é sempre superior ao egoísmo da minoria". (FEUERBACH, 1874, p. 345).
} 
lá, onde eu estou de acordo nos meus sentimentos e juízos com os outros.» (FEUERBACH, 1874, p. 105). A individualidade se estende não só às características estranhas, acentuadas, pelas quais o homem se diferencia de outros, mas também às qualidades que ele pensa em diferença daquelas como sociais e resume no conceito geral de homem. Em comparação ao animal ou, mais genericamente, em contraste com o ser distinto do homem, obviamente, desaparecem as diferenças entre os homens. «O homem é a essência próxima ao homem, igual segundo a essência. O outro é, na verdade, para mim, em tal relação, um ser, precisamente assim, diferente de mim, como o animal, a árvore» (FEUERBACH, 1971, GW 10, p. 343). Só em relação a si mesmos, os homens são essencialmente diferentes entre si, essencialmente, porque com a suprassunção de sua diferença é eliminada também a essência de sua individualidade. Embora o homem não seja de modo nenhum determinado tão exclusivo, inalterável e completamente, como está determinada a pedra ao cair no ar, o fogo ao queimar, assim sua essência não é, contudo, sequência de sua vontade, mas, pelo contrário, sua vontade sequência de sua essência, pois ele é antes que ele queira, e há ser sem querer, sem vontade, mas não vontade sem ser, sem o auxílio do meio material. Em suma, a vontade real é sempre apenas a vontade de uma essência determinada; querer quer dizer querer sempre algo determinado, e querer algo pressupõe ser algo. Aquele, que quer, então, não só quer, mas ele quer sempre algo. Um exemplo: todo homem diz: «eu quero, [mas] o primeiro: eu quero este romance; o outro: eu quero essa indescritível viagem; o terceiro: eu quero esta obra filosófica, mas todos provam pela diversidade de sua vontade apenas a diversidade de seu ser, que ele tem, na verdade, com a [...] vontade.» (FEUERBACH, 1874, p. 85). Já que a vontade pressupõe o ser, o homem deve, então, ser pela sua vontade, o que ele é apenas das condições do seu ser, de sua natureza.

O espiritualismo (Spiritualismus) é a doutrina oposta ao materialismo (Materialismus), que trata a liberdade, a vontade, e o pensamento diferente e independente do ser. De acordo com esta doutrina, o espírito (spiritus), (der Geist), tem sua raiz não no corpo, pois este é extenso, sensível e material. Que o espírito (ou alma) possa existir ou agir sem o corpo, é, por conseguinte, uma consequência necessária do espiritualismo, que designa a incorporeidade e a imaterialidade como a essência do espírito. Assim, Platão escreve no Fédon: "'As almas existiam antes do que elas eram em forma humana, sem corpo, e tinham entendimento e conhecimento."' (PLATON, 1974, 76c ${ }^{11}$. E adiante acrescenta ele: "Se a alma se serve do corpo, para tratar algo, seja mediante o ver ou algum outro sentido (pois por meio do corpo quer dizer, precisamente, tratar algo por meio dos sentidos), ela entra pelo corpo no variável; mas se ela trata algo para si mesma, então ela se dirige para o puro, para o que existe sempre e imutável."' (FEUERBACH, 1874, p. 126). Em Platão, a alma (die Seele) não está ligada, portanto, com o corpo, mas, pelo contrário, sem ele, para si mesma; ou seja, o ser da alma separada ou liberta do corpo identifica-se com seu ser-para-si-mesmo. Também Antilucretius, o qual Feuerbach cita, escreve, na quinta canção, o seguinte: '"o espírito está ligado com o corpo, mas ele pode viver sem o corpo.'” (FEUERBACH, 1874, p. 127). E Gassendi diz em suas Anotações para o décimo Livro de Diógenes L (Anmerkungen zum zehnten Buch des Diogenes $L$ ): "'O espírito ou o entendimento, a raiz da vontade, é imaterial ou incorpóreo e sem órgão (inorgânico), não misturado com a matéria, mas livre dela."' (FEUERBACH, 1874, p. 127). O mesmo afirma Tomás de Aquino em sua Summa:

A alma está separada (a saber, do corpo) segundo a força do pensamento ou do conhecimento, que não é a força de qualquer órgão corporal, assim como a força do ver é a atividade do olho; pois o pensamento é uma atividade que não pode ser exercida pelos órgãos corporais. [...] A alma humana não é por causa de sua perfeição uma forma

${ }^{11}$ Cf. também (FEUERBACH, 1874, p. 126). 
submersa na matéria corporal ou completamente envolvida por ela, e é, por conseguinte, nada desembaraçoso que ela não tenha uma força que não seja um ato corporal."' (AQUINO apud FEUERBACH, 1874, p. 128).

Mais adiante diz ele ainda: "'O princípio que pensa e conhece, chamado de espírito ou entendimento, tem uma atividade por si mesmo, em que o corpo não participa."' (AQUINO apud FEUERBACH, 1874, p. 128). Dito de forma curta, ele qualifica o pensamento como "uma atividade completamente imaterial." De reflexões semelhantes parte Descartes nas Meditações: "'É certo que eu sou realmente distinto do meu corpo e posso existir sem ele"' (DESCARTES, 1983, p. 134) ${ }^{12}$. E a seus adversários, ele responde: "'Não se deve acreditar que a força do pensamento seja, assim, ligada ao órgão corporal, que ela não possa existir sem o mesmo."' (DESCARTES, 1983, p. 153) ${ }^{13}$. Precisamente, das posições acima mencionadas, pode-se deduzir claramente que o espírito (der Geist) (a alma) foi tratado como uma essência imaterial, que está, na verdade, unida com o corpo (Leibe), mas pode existir do mesmo modo sem a própria corporeidade (Leiblichkeit). Embora alguns filósofos especulativos e "espiritualistas" tentem esclarecer a conexão entre espírito e corpo, ou fazê-la compreensível, esta tentativa, no entanto, segundo a opinião de Feuerbach, fracassou, pois o sentido do espiritualismo é, no fundo, não, precisamente, a ligação da alma com o corpo real, físico, mas, pelo contrário, a separação da mesma dele, "da matéria suja" (materiae contagio"). Além da incorporeidade (Unkörperlichkeit) e imaterialidade (Immaterialität), o espiritualismo tem também por fim a imortalidade da alma (Unsterblichkeit der Seele), pois ele é a doutrina da alma concebida para uma outra vida, para uma vida futura, isto é, para uma vida independente do fim da vida, da morte.

Como da doutrina da alma do espiritualismo só pode ser explicada a vida após a morte, mas não a vida antes dela, isto é, a vida real, presente, não se deixa também concluir dela nem a antropologia (o homem), nem a fisiologia (a natureza), mas apenas a teologia. No desejo religioso para a imortalidade (Unsterblichkeit), bem como para Deus, manifesta-se o desejo para uma liberdade, uma vontade livre, na qual vontade e capacidade, querer e poder, coincidem. Para a teologia, a imortalidade significa nada mais do que a alma livre da contradição de sua ligação com a matéria, e a alma mesma, como Deus, é para ela (a teologia) uma essência incorpórea, por conseguinte, não-espacial, embora ela (a alma) seja uma expressão da corporeidade e esteja conectada através da sua ligação com o corpo a um lugar, a saber, o corpo. Mas como a alma pode ao mesmo tempo estar e não estar num lugar? Como se explica a sua ilocalidade com a localidade, sua imaterialidade com sua materialidade? O espiritualismo argumenta aqui que o corpo não pertence à essência da alma (corpus non est essencia animae), por isso, a alma não termina na ligação, na união com ele; isto é, ela não se mistura essencialmente com ele. $\mathrm{Na}$ verdade, o espiritualismo aceita a localidade da alma, mas atribui a ela apenas uma extensão imaginária, nenhuma determinação material, física; a alma não existe para ele em algum lugar (in aliquo ubi), mas, por assim dizer, no lugar (ut in loco), que não é real. Em oposição a isto, é para Feuerbach a ligação da alma (do espírito) com o corpo a negação de todas as representações de incorporeidade, de ilocalidade ou imaterialidade da alma. Assim escreve ele: se «eu digo: a alma tem um corpo, eu digo in verdade: a alma é corporal, ela tem extensão e forma. De fato, é assim: a alma humana tem uma forma humana [...]. Se se quer, então, afirmar a alma imaterial, nega-se, assim, a sua ligação com o corpo, ou melhor, nega-se igualmente de preferência a existência dos corpos.» (FEUERBACH, 1874, p. 132). O espiritualismo, assim como o teísmo, tem "uma alma imaterial", apenas porque ele não precisa, no fundo, de uma existência concreta,

\footnotetext{
${ }^{12}$ Cf. também (FEUERBACH, 1874, p. 127).

${ }^{13}$ Cf. também (FEURBACH, 1874, p. 127).
} 
de um corpo; do mesmo modo, ele tem um Deus, porque ele também não precisa da natureza, do mundo. A necessidade de um Deus e da imortalidade da alma significa, na verdade, o desprezo (Missachtung) à natureza, a refutação (Widerlegung) da finitude e da limitação (Beschränktheit) do corpo, da corporeidade em geral. Para Feuerbach, o fundamento da alma, do espírito, não é a alma mesma, mas o corpo, não Deus, mas a natureza, pois se o homem provém de diferentes circunstâncias e condições da natureza, assim é o seu espírito, pelo menos em suas exteriorizações, dependente do corpo. O espírito é, portanto, finito (endlich) e limitado (beschränkt), já que ele está ligado ao corpo, à natureza. Espírito ligado ao corpo, à natureza, significa para Feuerbach homem; espírito sem a natureza é, ao contrário, Deus ou o próprio espírito da imaginação, da fantasia (Einbildungskraft) humana.

O espiritualismo filosófico, que pode ser aqui qualificado de idealismo, censura ao materialismo, que ele defende uma posição dogmática, porque ele parte da natureza sensível, ou seja, de um mundo que existe em si, como uma verdade constituída objetivamente, enquanto o mundo é, segundo a opinião do idealismo em geral, apenas um produto do espírito. A argumentação contra o materialismo, no modo de dizer de Feuerbach, reza da seguinte maneira:

Tu colocas as coisas como reais, como existindo fora de ti, apenas porque tu vês, ouves, sentes. Mas, ver, sentir, ouvir apenas sensações, apenas afecções de ti, apenas determinações de tua consciência, pois tu apenas vês, apenas sentes, quando tu és consciente de teu ver e sentir e de si mesmo. Tu sentes, então, não os objetos, mas apenas as sensações. Em toda percepção tu percebes sempre tua própria condição (FEUERBACH, 1874, p. 170).

Frente ao idealismo poder-se-ia formular a seguinte questão: pode um ser em geral manifestar seu sentimento, sua sensibilidade, se não existe um exterior, nada objetivo? Não sente, por exemplo, o gato, aproximadamente, a existência de seu objeto, o rato? Se o rato, que vê o gato, existisse, de fato, só em seus olhos ou fosse apenas uma afecção de seu ver, o gato não estenderia, então, suas unhas, em vez de para os ratos, de preferência para seus próprios olhos? E o homem? E o mundo é apenas, como diz Schopenhauer, uma representação e sensação do homem, ou ele existe também fora de sua representação? Depende o mundo, como ele aparece ao homem, apenas de seu próprio ser? Sente o homem realmente não o objeto, mas apenas a si mesmo, ou seja, sua representação do objeto? É o ar, que o homem inala com a ajuda dos poros de sua pele e dos pulmões, apenas uma sensação ou uma representação dele? De facto, o homem respira o ar real, como ele é, já que ele não pode viver sem ele. E a percepção, a sensação de fome e sede, é ela uma coisa vazia, não-objetiva, pura da consciência? Não é a sede outra coisa que apenas a necessidade de um objeto sentido, a saber, a falta de líquido? Feuerbach aceita o fato de que o eu como sedento tenha sede somente em relação a si mesmo, a seu eu. No entanto, ele se sente, mas como um ser que precisa da água, pois «sem água», "eu me sinto como um eu [...] altamente deficiente, infeliz, miserável." (FEUERBACH, 1874, p. 178). E mais adiante Feuerbach expõe: fome e sede são "sensações de desconforto [...], porque eu [...] não sou um homem inteiro sem comida e bebida. Por que [..]? Porque aquilo, que eu como, o que eu bebo, é [...] de meu ser, como eu sou de meu ser.» (FEUERBACH, 1874, p. 178-179). Embora a sensação possa ocorrer apenas para si mesma, ela se refere, então, necessariamente a um objeto; ela é subjetiva, mas seu fundamento é objetivo, pois o homem sente, por exemplo, sede, porque a água, que ele precisa para saciar sua sede, não é resultado de suas sensações ou representações, mas, pelo contrário, objetiva e existe independente delas. A água é um elemento essencial no homem e fora dele, a base ou a condição para sua existência e para a própria sensação.

Abstraindo destas condições naturais inevitáveis, da objetividade, rejeita o idealismo o materialismo, pois este faz de um ponto de vista inteiramente invertido o seu ponto de partida; 
ele parte do objeto em vez do sujeito, do não-eu em vez do eu, na medida em que ele faz "do deduzido", "do segundo" (a natureza, o ser) o primeiro. O materialismo de Feuerbach, para o qual a natureza, o ser, precede o pensar, concorda com o idealismo num ponto, a saber, que o mundo, o ser, apesar de sua independência, não pode ser apreendido e compreendido sem o eu (o sujeito). O problema consiste, porém, nisto, que o eu, do qual o idealismo parte, isto é, o eu, que supera a existência das coisas sensíveis, não tem para si mesmo existência, pois:

uma existência sem estômago, sem sangue, sem coração, consequentemente, por último, também sem corpo é uma existência altamente duvidosa, que não me dá a certeza de minha existência, em que eu não me reconheço e me acho, uma existência que nada mais é do que minha não-existência pensada como existência, uma existência que se dissolve [...] em nada.» (FEUERBACH, 1971, GW 10, p. 231).

O conceito idealista do eu parte, então, de um eu puramente pensado, e não de um eu real. Mas este eu está corporalmente, espaço-temporalmente condicionado; ele é "apenas eu feminino ou masculino, não um neutro assexuado, pois a diferença de sexo é [...] uma marca, [...] uma diferença penetrante, onipresente.» (FEUERBACH, 1874, p. 173). Disto resulta a tese de Feuerbach, que só existe um eu, que é essencialmente eu e tu, sujeito-objeto, ou seja, uma essência fundada para o outro. Assim, conduz Feuerbach o eu aqui para sua relação com o tu, com o mundo objetivo, pois o eu que existe, real, é apenas o eu, ao qual está de frente um tu, e este tu, ao qual está de frente de um eu, não é, como vimos antes, só o tu humano. Por baixo disto, está antes para subsumir também o objeto, a realidade e a objectividade da natureza (do mundo). A falta fundamental do idealismo consiste, segundo Feuerbach, nisto, a saber, que fica parado no ponto de vista do entendimento, no ponto de vista teórico, na questão do caráter objetivo ou subjetivo do mundo, da realidade ou irrealidade da natureza, enquanto que a natureza é originalmente um objeto do ser e só através deste um objeto do entendimento. A natureza, assim como ela é objetivamente, independentemente, é, portanto, nenhuma representação do pensamento, mas a base, o fundamento do mesmo, o pressuposto e a condição natural do processo de produção e reprodução da vida humana e também de realização de sua liberdade.

\section{Referências}

\section{Literatura Preliminar}

FEUERBACH, L. Über Spiritualismus und Materialismus, besonders in Beziehung auf die Willensfreiheit. Org. por W. Schuffenhauer. Berlin: Akademie-Verlag, 1972, GW 11.

FEUERBACH, L. Zur Moralphilosophie. In: Nachlass. Organizado por Karl Grün. Leipzig \& Heidelberg: C. F. Winter'sche Verlagshandlung, 1874, Bd. II.

FEUERBACH, L. Darstellung, Entwicklung und Kritik der Leibnizschen Philosophie. Org. por W. Schuffenhauer. Berlin: Akademie-Verlag, 1969, GW 3.

FEUERBACH, L. Die Unsterblichkeitsfrage vom Standpunkt der Anthropologie. Org. por W. Schuffenhauer. Berlin: Akademie-Verlag, 1971, GW 10.

FEUERBACH, L. Das Wesen Des Christentums (1841). Berlin, 1973, GW 5.

FEUERBACH, L. Vorlesungen über das Wesen der Religion (1851). Nebst Zusätzen und Anmerkungen. Berlin, 1967, GW 6

FEUERBACH, L. Vorlesungen über die Geschichte der neueren Philosophie (Von G. Bruno bis G. W. F. Hegel, Erlangen 1835-1836), bearb. v. C. Ascheri u. E. Thies. Darmstadt, 1974. 
FEUERBACH, L. Einleitung in die Logik und Metaphysik (Erlangen 1829-1830), bearb. v. C. Ascheri u. E. Thies. Darmstadt, 1975.

FEUERBACH, L. Vorlesungen über Logik und Metaphysik (Erlangen 1830-1831). bearb. v. C. Ascheri u. E. Thies. Darmstadt, 1976.

FEUERBACH, L. Philosophischen Charakterentwicklung. hrsg. v. K. Grün, 2 Bde. Leipzig/Heidelber, 1874.

FEUERBACH, L. Etica e Felicità - Con una Raccolta di Aforismi di Argomento Morale. Edizione Guerini e Associati: Milano, 1997.

\section{Literatura Complementar}

ARNDT, Andreas; JAESCHKE, Walte (Hrsg.). Materialismus und Spiritualismus. Philosophie und Spiritualismus. Philosophie und Wissenschaften nach 1848. Hamburg, 2000.

ARVON, Henri. Ludwig Feuerbach ou la transformation du sacré. In: Archives de sociologie des religions, n. 3, 1957.

ASCHERI, Carlo. Feuerbachs Bruch mit der Spekulation. Einleitung zur kritischen Ausgabe von Feuerbach: Notwendigkeit einer Veränderung (1842). Wien, 1969.

BAL, Karol. Naturwissenschaft und Revolution. Ein Kommentar zu Feuerbach. In: BRAUN, H. J.; SASS, H. M.; SCHUFFENHAUER, W.; TOMASONI, F. (Hrsg.). Ludwig Feuerbach und die Philosophie der Zukunft. Berlin, 1989, p. 69-76.

BARATA-MOURA, José (Org.). Esclarecer significa fundamentar. Alienacão e alteridade em Das Wesen des Christentums de Ludwig Feuerbach. In: Pensar Feuerbach. Colóquio comemorativo dos 150 anos da publicacão de "A Essência do Cristianismo", Lisboa, 1993, p. 47-93.

BIBEL, Hrsg. v. der Evangelioschen Kirche in Deutschland. Stuttgart, 1985.

BIEDERMANN, Georg. Der anthropologische Materialismus Ludwig Feuerbachs. Höhepunkt und Abschluss der klassischen deutschen Philosophie. Neustadt, 2004.

BRAUN, H-J. Ludwig Feuerbachs Lehre vom Menschen. Stuttgart-Bad Cannstatt: Friedrich Frommann Verlag, 1971.

ders.: Die Religionsphilosophie Ludwig Feuerbachs. Stuttgart: Bad Cannstatt, 1972.

CHAGAS, Eduardo F. Natureza e Liberdade em Feuerbach e Marx. Campinas: Editora Phi, 2016, 226p.

CHAGAS, Eduardo F.; Redyson, Deyve. Ludwig Feuerbach: filosofia, religião e natureza. São Leopoldo: Editora Nova Harmonia, 2011.

CHAGAS, Eduardo F. A Aversão do Cristianismo à Natureza em Feuerbach. Philósophos Revista de Filosofia. Goiânia, v. 15, n², 2010.

CHAGAS, Eduardo F. A Religião em Feuerbach: Deus não é Deus, mas o Homem e/ou Natureza divinizados. Dialectus Revista de Filosofia. Fortaleza, nº 04, 2014.

CHAGAS, Eduardo F. Homem e Natureza em Ludwig Feuerbach. Fortaleza: Edições UFC, 2009. (Série Filosofia $n^{\circ} 8$ ).

CHAGAS, Eduardo F. A Razão em Feuerbach como base da unidade do homem e da natureza. Princípios Revista de Filosofia. Natal, v.14, n²1, jan./jun. 2007.

CHAGAS, Eduardo F. Feuerbach e Espinosa: deus e natureza, dualismo ou unidade? Trans/Form/ Ação Revista de Filosofia. São Paulo, v. 29, n², 2006. 
CHAGAS, Eduardo F. A Questão do Começo na Filosofia de Hegel - Feuerbach: Crítica ao começo da Filosofia de Hegel na Ciência da Lógica e na Fenomenologia do Espírito. Revista Eletrônica de Estudos Hegelianos. Recife, v. 2, n 1, 2005.

CHAGAS, Eduardo F. Religião: O homem como imagem de Deus ou Deus como imagem do homem? In: OLINDA, Ercília Maria Braga. Formação Humana: Liberdade e Historicidade. Fortaleza: Edufc, 2004.

CHAGAS, Eduardo F. A Autonomia da Natureza em Ludwig Feuerbach. In: VASCONCELOS, José Gerardo. (Org.). Filosofia, Educação e Realidade. Fortaleza: Edufc, 2003.

CHAGAS, Eduardo F. A Comunidade Ilusória: a teoria do estado no jovem Marx. ljuí: Editora Unijuí,1998.

CHAGAS, Eduardo F. A Cisão do Mundo Ético: Lei Divina e Lei Humana na Fenomenologia e na Antígona. Revista de Educacão e Filosofia. Uberlândia, n 15, 1994, p. 67-74.

CHAGAS, Eduardo F. Projeto de uma nova Filosofia como Afirmacão do Homem em Ludwig Feuerbach. Teoria \& Praxis Revista de Ciências Humanas e Política. Goiânia, n 4, 1992, p. 31-36.

CORNEHL, Peter. Feuerbach und die Naturphilosophie. Zur Genese der Anthropologie und Religonskritik des jungen Feuerbach. In: Neue Zeitschrift für systematische Theologie und Religionsphilosophie. Bd. 11, Berlin, 1969, p. 37-93.

DESCARTES, R. Meditação Sexta. In: Meditações. São Paulo: Abril Cultural, 1983. (Os Pensadores). DESCARTES, R. Respostas do Autor às Segundas Objeções. In: Objeções e Respostas. São Paulo: Abril Cultural,1983. (Os Pensadores).

DLOUGATCH, Tamara. Der Begriff "Natur" bei Rousseau und Feuerbach: Vom Sentimentalismus zum Anthropologismus. In: JAESCHKE, W. ; TOMASONI, F. (Hrsg.). Ludwig Feuerbach und Geschichte der Philosophie. Berlin, 1998. p. 260-268.

EIDAM, Heinz. Vom Wert der Natur und der Natur des Werts. Thesenartiges zu deren Verhältnis und dessen Diskussion. In: EIDAM, H.; SCHMIED-KOWARZIK, W. (Hrsg.). Natur - Ökonomie Dialektik. Weitere Studien zum Verhältnis von Natur und Gesellschaft. Kassel, 1989. p. 113-129.

ENGELS, Friedrich. Ludwig Feuerbach und der Ausgang der klassischen deutschen Philosophie. MEW, Bd. 21, Berlin, 1984.

FICHTE J.G. System der Sittenlehre. Werke auf CD-ROM. Berlin, 1997.

HAENSCH, Gerd. Ludwig Feuerbachs Beitrag zur Klarung des Begriffs "Pantheismus". In: Zum 175. Geburtstag von Feuerbach, Deutsche Zeitschrift für Philosophie 27, Berlin, 1979, p. 699-714.

HARICH, Wolfgang. Einleitung zu Feuerbachs Schrift. Zur Kritik der Hegelschen Philosophie. Berlin, 1955.

HEGEL, Georg Wilhelm Friedrich. System der Philosophie I. Stuttgart, 1958.

HEGEL, Georg Wilhelm Friedrich.Janaeer Systementwürfell. Logik, Metaphysik, Naturphilosophie. Hrsg. V. R.P. Horstmann. Hamburg, 1982.

HEGEL, Georg Wilhelm Friedrich. Phänomenologie des Geistes. Hrsg. v. W. Bonsiepen u. R. Heede, Hamburg, 1999.

HEGEL, Georg Wilhelm Friedrich. Wissenschaft der Logik. Hrsg. v. F. Hogemann u. W. Jaeschke, Hamburg, 1999.

HEGEL, Georg Wilhelm Friedrich. Enzyklopädie der philosophischen Wissenschaften im Gründrisse. Hrsg. v. U. Rameil u. H. Christian, Hamburg, 1999. 
HEGEL, Georg Wilhelm Friedrich. Grundlinien der Philosophie des Rechts. Hrsg. v. J. Hoffmeister. Hamburg, 1999.

HOMERO. Ilias. Tradução de R. Hampe. Stuttgart: Reclam, 1979.

HOMMES, Ulrich. Hegel und Feuerbach. Eine Untersuchung der Philosophie Feuerbachs in ihrem Verhältnis zum Denken Hegels. Freiburg, 1957.

HÖPPNER, Joachim. Ludwig Feuerbach und seine materialistische Weltanschauung in ihrer historischen Bedeutung für die wissenschaftliche Philosophie. Leipzig, 1960.

HÜSSER, Heinz. Natur und Religion in der Religionskritik Ludwig Feuerbachs. Betrachtungen zu einem aktuellen Problem. In: BRAUN, H.J. (Hrsg.). Ludwig Feuerbach und die Philosophie der Zukunft. Berlin, 1989. p. 39-54.

HÜSSER, Heinz. Die Menschwerdung der Natur. In: BRAUN, H.J. (Hrsg.). Würzburg, 1993.

JESSIN, I. M. Die materialistische Philosophie Ludwig Feuerbachs. Berlin, 1956.

KOSING, Alfred. Ludwig Feuerbachs materialistische Erkenntnistheorie. In: THIES, E. (Hrsg.). Ludwig Feuerbach. Darmstadt, 1976, p. 310-341.

LANGE, Friedrich Albert. Geschichte des Materialismus und Kritik seiner Bedeutung in der Gegenwart. 2 Bde. Leipzig, 1906.

LEFÈVRE, Wolfgang. Wissenschaft und Philosophie bei Feuerbach. In: JAESCHKE, W. (Hrsg.). Sinnlichkeit und Rationalität. Berlin, 1992. p. 81-100.

LENIN, Wladimir I. Materialismus und Empiriokritizismus. In: Werke, Bd. 14. Berlin, 1964.

LENIN, Wladimir. Konspekt zu Feuerbachs „Vorlesungen über das Wesen der Religion“ und zur Feuerbachschen Darstellung, Entwicklung und Kritik der Leibnizschen Philosophie. In: Werke, Bd, 38. Berlin, 1964. p. 41-76.

LEY, Hermann. Ludwig Feuerbach über das Bündnis von Philosophie und Naturwissenschaft und der dialektische Materialismus. In: Referentenkonferenz der zentralen Kommission Wissenschaft. Berlin, 1972. p. 70-78.

LENIN, Wladimir. Ludwig Feuerbach und die Natur. In: LÜBBE, H.; SAß, H.M. (Hrsg). Atheismus in der Diskussion. Kontroversen um Ludwig Feuerbach. München, 1975. p. 120-141.

MARX, Karl. Ökonomisch-philosophische Manuskripte (1844). In: MEW, Ergänzungsband. Berlin, 1968.

MARX, Karl. Das Kapital. MEW, Bd. 1. Berlin, 1977.

MARX, Karl; ENGELS, Friedrich. Die heilige Familie. In: MEW, Bd. 2. Berlin, 1958.

MARX, Karl; ENGELS, Friedrich. Die deutsche Ideologie. In: MEW, Bd. 3. Berlin, 1969.

MARX, Karl; ENGELS, Friedrich. These über Feuerbach. In: MEW, Bd. 3. Berlin, 1969.

MEYER, Martin. Ludwig Feuerbachs Moralphilosophie in ihrer Abhängigkeit von seinem Anthropologismus und seiner Religionskritik, phil. Diss. Berlin, 1899.

MIRNAM, Ebrahim. Feuerbachs Entwicklung Vom Idealismus zum Materialismus unter besonderer Berücksichtigung der Bestimmungen des Denkens, des Bewußtseins und des Selbstbewußtseins. Frankfurt a. M., 1998.

MÜNZ, Theodor. Spinoza, Feuerbach und die Würde der Natur. In: BRAU, H.; SASS, M.; SCHUFFENHAUER, W.; TOMASONI, F. (Hrsg.). Ludwig Feuerbach und die Philosophie der Zukunft. Berlin, 1989. p. 55-67. 
NIKOLAJEW, I. W. Die wesentlichen Entwicklungsetappen der Kategorie "Materie". In: PFOH, W.; SCHULZE, H. (Hrsg.). Philosophie und Gesellschaft. Berlin, 1958. p. 205-222.

PLATON. Phaidon. Tradução de Friedrich Schleiermacher. Darmstadt: Wissenschaftliche Buchgesellschaft, 1974, Werke, Bd. 3.

RAWIDOWICZ, Simon. Ludwig Feuerbachs Philosophie. Ursprung und Schicksal. Berlin, 1964.

REITEMEYER, Ursula. Philosophie der Leiblichkeit. Ludwig Feuerbachs Entwurf einer Philosophie der Zukunft. Frankfurt a. M., 1988.

REITEMEYER, Ursula. "Why Feuerbach is both Classic and Modern". In: SCHNEIDER, Katharina (Hrsg.). Der politische Feuerbach. Münster: Waxmann, 2013, p.163-167.

ROHRMOSER, Günther. Warum sollen wir uns für Feuerbach interessiert? In: THIES, E. (Hrsg). Ludwig Feuerbach. Darmstadt, 1976. p. 483-514.

SCHMIDT, Alfred. Emanzipatorische Sinnlichkeit. Ludwig Feuerbachs anthropologischer Materialismus. München, 1973.

SCHMIDT, Alfred. Feuerbachs Stellung in der Geschichte des Materialismus. In: THIES, E. (Hrsg). Ludwig Feuerbach. Darmstadt, 1976. p. 405-430.

SCHMIDT, Alfred. Der Begriff der Natur in der Lehre von Marx. Frankfurt a. M., 1978.

SCHMIED-KOWARZIK, Wolfdietrich. Das dialektische Verhältnis des Menschen zur Natur: Philosophiegeschichtliche Studien zur Naturproblematik bei Karl Marx. Freiburg, 1984.

SCHMIED-KOWARZIK, Wolfdietrich. Die Entfremdung der gesellschaftlichen Produktion von der Natur und ihre revolutionäre Überwindung. In: IMMLER, H.; SCHMIED-KOWARZIG, W. (Hrsg.). Marx und die Naturfrage. Hamburg, 1984. p. 9-20.

SCHMIED-KOWARZIK, Wolfdietrich. Weder Arbeit noch Natur sind wertbilden, aber sie sind die Quellen allen Reichtums. In: IMMLER, H.; SCHMIED-KOWARZIG, W. (Hrsg.). Marx und die Naturfrage. Hamburg, 1984. p. 45-63.

SCHMIED-KOWARZIK, Wolfdietrich. Ohne Kenntnis des Ziels führen die Wege in die Irre. In: IMMLER, H.; SCHMIED-KOWARZIG, W. (Hrsg.). Marx und die Naturfrage. Hamburg, 1984. p. 111-135.

SCHMIED-KOWARZIK, Wolfdietrich. Auch richtige Fragen können zu falschen Antworten führen. In: IMMLER, H.; SCHMIED-KOWARZIG, W. (Hrsg.). Natur und Marxistische Wertheorie. Kassel, 1986. p. 47-64.

SCHMIED-KOWARZIK, Wolfdietrich. Die Aporie der Naturfrage im Marxismus und ihre dialektische Lösung bei Marx. In: EIDAM, H.; SCHMIED-KOWARZIK, W. (Hrsg.). Natur - Ökonomie - Dialektik. Weitere Studien zum Verhältnis von Natur und Gesellschaft. Kassel, 1989. p. 19-33.

SCHMIED-KOWARZIK, Wolfdietrich. "Von der wirklichen, von der seyenden Natur": Schellings Ring um eine Naturphilosophie in Auseinandersetzung mit Kant, Fichte und Hegel. Stuttgart-Bad Cannstatt, 1996.

SCHRÖTER, Gisela. Zum Bündnis von Philosophie und Naturwissenschaft im Materialismus Ludwig Feuerbachs. In: Deutsche Zeitschrift für Philosophie, Heft 36, Jahrgang. Berlin, 1988, p. 28-36.

SCHUFFENHAUER, Werner. Ludwig Feuerbach und der junge Marx. Zur Entstehungsgeschichte der marxistischen Weltanschauung. Berlin, 1965.

SCHUFFENHAUER, Werner. Materialismus und Naturbetrachtung bei Ludwig Feuerbach. In: Deutsche Zeitschrift für Philosophie (Dzfph.), 20. Berlin, 1972. p. 1461-1473. 
SCHUFFENHAUER, Werner.Ludwig Feuerbachs Bedeutung in unserer Zeit.In:Referentenkonferenz der zentralen Kommission Wissenschaft (Deutscher Kulturbund). Berlin, 1972. p. 7-28.

SCHUFFENHAUER, Werner. „Aut Deus - Aut Natu“. Zu Ludwig Feuerbachs Spinoza- und LeibnizBild. In: Lo spinozismo ieri e oggi - Archivio di Filosofia. Padova, 1978, n 1, p. 267-291.

SENECA. Über den Zorn. Drittes Buch. In: ROSENBACH, Manfred. (Hrsg.). Philosophische Schriften. Darmstadt: Wiss. Buchges, 1999, Bd. 1; Bd. 3.

SERRÃO, Adriana Veríssimo. Da razão ao homem ou o lugar sistemático de A Essência do Cristianismo. In: BARATA-MOURA, J. (Org.). Pensar Feuerbach - Colóquio comemorativo dos 150 anos da publicacão de "A Essência do Cristianismo". Lisboa, 1993. p. 11-22.

SERRÃO, Adriana Veríssimo. Natura Mater. O Habitar Ètico na Natureza Segundo Ludwig Feuerbach. In: Pensar a Sensibilidade: Baumgarten - Kant - Feuerbach. Lisboa: Universitas Olisiponensis, 2007.

SERRÃO, Adriana Veríssimo. Sentimento da Natureza e imagem do Homem. Kant e Feuerbach. Simmel: Philosophica, v. 30, 2007.

SÓFOCLES. Antígone. Traduzido por W. Kuchenmüller. Stuttgart: Reclam, 2000.

SOUZA, Draiton Gonzaga de. O ateísmo antropológico de Ludwig Feuerbach. Porto Alegre: Edipucrs, 1993.

SOUZA, Draiton Gonzaga de. Zur Ethik Ludwig Feuerbachs. Göttingen, 1998.

SPINOZA, Benedictus. Ethik. GEBHARDT, C. (Hrsg.). Stuttgart, 1997.

STEINDL, Regina. Bemerkungen zum Naturbegriff bei Ludwig Feuerbach. In: Wissenschaftliche Reihe 34, H. 3. Jena, 1985, p. 361-366.

THIES, Erich. Philosophie und Wirklichkeit. Die Hegelkritik Ludwig Feuerbachs. In: THIES, E. (Hrsg.). Ludwig Feuerbach. Darmstadt, 1976. p. 431-482.

TOMASONI, Francesco. Ludwig Feuerbach. Biografia intellettuale. Editrice Morcelliana, 2011.

TOMASONI, Francesco. Ludwig Feuerbach e la natura non uman: Riconstruzione genetica dell' „Essenza della religione“ con pubblicazione degli inediti. Firenze 1986.

TOMASONI, Francesco. Feuerbachs Kritik der Wissenschaftsideologie und Evolutionstheorien. In: BRAUN, J.; SASS, W.; SCHUFFENHAUER, M.; TOMASONI, F. (Hrsg.). Ludwig Feuerbach und die Philosophie der Zukunft. Berlin, 1989. p. 77-92.

TOMASONI, Francesco. Ludwig Feuerbach und die nicht-menschliche Natur. Stuttgart-Bad Cannstadt, 1990.

VUILLEMIN, Jules. La signifikation de l'humanisme athée chez Feuerbach et l'idee de nature. In: Deucalion 6, 1952, p. 17-46.

WIDMAN, Hans Joachim. Ludwig Feuerbachs Moralphilosophie. Hamburg, 1979.

WINTZER, Wilhelm. Die ethischen Untersuchungen Ludwig Feuerbachs. phil. Diss. Leipzig, 1898.

XHAUFFLAIRE, Marcel. Feuerbach et la théologie de la sécularisation. Paris, 1970.

Sobre o autor

Eduardo Ferreira Chagas

Pós-Doctor em Filosofia pela Universität von Münster (Alemanha) (2019); Doutor em Filosofia pela Universität von Kassel (Alemanha) (2002); Mestrado em Filosofia pela Faculdade de Filosofia e Ciências Humanas (FAFICH) da 
Universidade Federal de Minas Gerais (UFMG, 1993); Graduado em Filosofia pela Universidade Estadual do Ceará (UECE, 1989). Professor Bolsista-Pesquisador do CNPq. É professor efetivo (associado) do Curso de Filosofia e do Programa de Pós-Graduação em Filosofia da Universidade Federal do Ceará (UFC) e Professor Colaborador do Programa de Pós-Graduação em Educação Brasileira da FACED - UFC.

Atualmente, é pesquisador bolsista de produtividade CNPQ, é membro da Internationale Gesellschaft der FeuerbachForscher (Sociedade Internacional Feuerbach) e dedica suas pesquisas ao estudo da filosofia política, da filosofia de Hegel, do idealismo alemão e de seus críticos Feuerbach, Marx, Adorno e Habermas. E-mail: ef.chagas@uol.com.br. Homepage: http://efchagasufc.wordpress.com/. Editor da Revista Dialectus (http://www.revistadialectus.ufc.br/ index.php/RevistaDialectus/ about/editorialPolicies\#sectionPolicies). C.V (Lates): http://lattes.cnpq.br/247989 9457642563.

Recebido em: 05/05/2020

Aprovado em : 25/07/2020 